\title{
Research on the Input, Use and Management of Undergraduate Teaching Funds in Universities-Taking a Local University as an Example
}

\author{
Qing Yang ${ }^{1, *}$
}

${ }^{1}$ Finance Office, Tianjin Agricultural College, Tianjin, China

*Corresponding author. Email: 495060945@qq.com

\begin{abstract}
The management of undergraduate teaching funds is conducive to improving the teaching quality of colleges and universities. This article first defined the research scope of teaching funds to identify research subjects. Secondly, by making an analysis of the expenditure data of teaching funds in a local university, the budgeting of teaching funds and the setting of relevant indicators, the author analyzed the problems existing in the input, use and management of undergraduate teaching funds in this university. Finally, this article put forward countermeasures to perfect the use and management of undergraduate teaching funds in this university so that its efficiency and effect can be great improved.

Keywords: university; teaching funds; input; use; management
\end{abstract}

\section{INTRODUCTION}

With the increase of teaching funds in colleges and universities, the problems of education quality and effective use of education funds have become increasingly prominent. How to make better use of these teaching funds has become an urgent issue to be addressed in colleges and universities. According to the survey of undergraduate teaching funds in this university, the current problems exist in the process of teaching funds input, use and management, which can directly affect the quality of college teaching and talent training. So, how to make better use of these teaching funds has been one of the priorities of colleges. To find a solution can help universities strengthen their own construction, optimize the teaching links, improve the quality of teaching and school-running level, promote the teaching reform, expand the methods of teaching reform, perfect the measures of teaching reform. As a result, the ultimate goal of training high-quality talents can be achieved. Taking a local university as an example, the author tried to make the use of local university education funds more efficient and provide a certain theoretical basis for the government and local universities to make their decisions.

\section{THE CONCEPT OF UNDERGRADUATE TEACHING FUNDS}

Teaching funds can be divided into two kinds from the broad sense and narrow sense. In the broad sense, teaching funds refer to all kinds of funds occurring in the development of higher education. However, some expenditures in colleges and universities are not very related to practical teaching, such as teaching staff salary, social insurance, retired personnel expenses, logistics support expenses and other expenses. The broad sense of teaching funds covers a wide range, so it is hard to make related research. And such research lacks practical sense. In the narrow sense, only the expense that is directly related to the teaching process can be called teaching funds. However, the financial project allocation is influenced by local fiscal revenue and national policies. The amount of financial allocation can change every year, and it is beyond the control ability of the university. So, this part of teaching funds is excluded. This paper mainly focuses on the basic funds expenditure of undergraduate teaching, including the daily operation expenditure of undergraduate teaching, experiment, internship, teaching reform and professional construction. This paper does not cover the expenditure of teaching reform and specialty construction, because such expenditure is arranged by finance department in this university. Undergraduate teaching daily operating expenses cover office, travel, labor costs, special materials, paper layout, training, conference and other academic institutions. 
Table 1. Investment in Teaching Funds 2017-2019 (ten thousand yuan)

\begin{tabular}{|c|c|c|c|c|c|}
\hline Year & $\begin{array}{c}\text { Number of } \\
\text { undergraduates }\end{array}$ & $\begin{array}{c}\text { Daily operating } \\
\text { expenses of } \\
\text { teaching }\end{array}$ & $\begin{array}{c}\text { Expenditure of } \\
\text { experimental funds }\end{array}$ & $\begin{array}{c}\text { Internship } \\
\text { expenses }\end{array}$ & $\begin{array}{c}\text { Expenditure on daily } \\
\text { operation of teaching per } \\
\text { student (yuan) }\end{array}$ \\
\hline 2017 & 11147 & 4578.19 & 872.37 & 154.9 & 4107.1 \\
\hline 2018 & 11523 & 7539.46 & 463.85 & 167.63 & 6542.97 \\
\hline 2019 & 12465 & 8177.74 & 727.07 & 299.46 & 6560.56 \\
\hline
\end{tabular}

\section{PROBLEMS EXISTING IN THE USE AND MANAGEMENT OF UNDERGRADUATE TEACHING FUNDS}

\subsection{Improve the use of teaching funds and the professional ability of management personnel}

The budgeting of academic institutions is generally done by the administrative staff who do not understand the meaning of the indicators. And they tend to have a vague understanding of budgeting as well as the measurement and allocation of related expenditures. Budgeting is finished in a random, unreasonable and unscientific way. The administrative staff have no plans when preparing budget. And they usually arbitrarily determine the amount of funds without referring to real expenditure data, and then pass the buck to financial personnel.[2] Because financial personnel cannot identify the specific needs on the detailed funds situation of academic institutions, they can only combine with the specific implementation and the budgeting of the previous year. As a result, it will lead to a discrepancy between the budgetary funds and the actual demand, like insufficient budget or surplus in the process of budget implementation.

\subsection{Insufficient investment in teaching funds}

The three-consecutive-year teaching daily operating expenditure shows that the daily operating expenditure of teaching expenditure increased year by year. In 2019, the expenses of internship and experiment respectively accounted for $3.66 \%$ and $8.89 \%$ of the daily teaching operating expenses respectively, indicating that while the daily teaching operating expenses increased, the expenses of internship and experiment were still relatively small. From the perspective of per student expenditure, the per student internship expenditure in 2019 was 240.24 yuan, which was relatively small for universities focusing on natural science disciplines. The past three years have witnessed the great fluctuation of the experimental expenditure. According to the calculation of the highest experimental expenditure in 2017, the average experimental expenditure of each student is 782.61 yuan, which is still at a rather low level. It shows that while the teaching daily operation funds increase year by year, the experimental funds and practice funds are still insufficient.

\subsection{Unreasonable internal allocation and use of teaching funds}

The experimental funds are managed by the Office of Academic Affairs, and all the use requires the approval and signature of the Office of Academic Affairs. The funds are not allocated to the academic institutions according to the needs of professional disciplines, so the actual demands of the experimental funds cannot be directly reflected. Teaching funds are mainly used by academic institutions and the Office of Academic Affairs. When using funds, faculties and even the Office of Academic Affairs lack a clear understanding of the scope for using funds, so it is often not implemented in accordance with relevant systems. At present, academic institutions only set up teaching business funds items, which are too general and easy to be occupied and reduced. So it's hard to achieve the due effect of teaching funds. In addition, academic institutions fail to take the various demands of different disciplines into their consideration when compiling the budget. The internal funds allocation also fail to be connected with the previous experience and the actual situation of faculties. The process of setting targets tends to be manually finished, which easily leads to the one-size-fits-all phenomenon.

\subsection{The budget complication of teaching funds lacks evaluation mechanism}

After the deviation exists between the teaching funds budgeting and the actual implementation, it is not timely adjusted in the future annual budgeting during referring to the implementation situation. Budgeting is just connected with the formality, and there is no mid-term adjustment in budget implementation. Besides, no corresponding evaluation mechanism was carried out after budget implementation. Although the annual report of undergraduate teaching quality is compiled every academic year, the report only involves the daily operating expenses of teaching, undergraduate experimental funds and 
internship funds during that year. It fails to cover other comparison indicators. The finance department did not make relevant analysis of the data that are filled in, especially the budget implementation and the effect of the funds using. In addition, it did not use key indicators to assess the budget implementation[2]. No corresponding reward and punishment mechanism has been established for evaluating the budget implementation of academic institutions.

\section{COUNTERMEASURES TO PERFECT THE USE AND MANAGEMENT OF TEACHING FUNDS}

\subsection{Improve the professional ability of personnel related to teaching funds}

Before the budgeting, the budgeting training among managerial personnel of academic institutions should be launched, which can help them learn how to make budgeting and then reasonably calculate the budget amount based on the real demands of academic institution. Finally, they are able to make reasonable budgeting. In budget implementation, it is necessary to combine the real condition of funds using and make timely adjustment so as to avoid crowding, misappropriation, insufficient or surplus funds.[6] Financial personnel should strengthen the investigation and understanding of teaching, analyze whether the budget of academic institutions is reasonable, which can be finished on the basis of referring to the relevant data of the previous year. Then the funds management can be jointly finished.

\subsection{Reasonable allocation of teaching funds}

\subsubsection{Detail teaching business expenses}

The funds of academic institutions in this university are only set up for teaching business expenses, and there is no corresponding subdivision according to expenditure categories, which is not conducive to distinguishing the funds using of managerial staff and teaching staff in academic institutions. Teaching business expenses should be detailly divided into specific expenditure categories, such as office expenses, travel expenses, materials and other teaching-related expenses, which can be set up according to the actual needs of academic institutions.

\subsubsection{Decentralize the authority of funds management}

At present, the total amount of experiment and internship funds is managed and approved by the academic affairs department, not allocated to each academic institution. The use of internship and experiment funds should be allocated to each academic institution in accordance with certain standards. The allocated targets should be managed by the faculty and jointly supervised by the academic affairs department and the finance department. The indicators are decentralized to each academic institution, which can more intuitively reflect the use of experimental funds of each college and provide data support for the comparative analysis of funds. It can also provide basis for future annual budgeting and help calculate the relevant indicators more reasonably and accurately.

\subsubsection{Increase the input of key funds}

The investment of internship funds and experiment funds is in direct proportion to students' satisfaction degree and the training of future working ability. According to the average expenditure of current internship and experiment funds, the investment of teaching funds is still insufficient, and the allocation should be tilted towards the internship and experiment funds. Since this university includes agriculture, engineering, management, science, economics and other disciplines, the internship and experiment funds of various disciplines should be different from each other[1]. And the previous data should be connected to reasonably determine the index amount of related funds.

\subsection{Reasonably make the teaching funds budgeting}

At present, the budgeting of each academic institution is made in an arbitrary and impractical way. The finance department is supposed to provide the academic institution with the funds using in previous years for reference. In the annual budgeting, it's of great necessity to consider the rationality of teaching funds budgeting, the practical demands of teaching and the maximal use of related funds. It's wise to increase the investment in relevant funds that affect teaching quality and students' satisfaction. As for the specific use process, strictly obey the expenditure spending requirements, and avoid squeezing and occupying funds. And the timely adjustment should be made in time based on the real use condition and actual needs.

\subsection{Introduce a performance evaluation mechanism}

Supervision should be strengthened in the whole budgeting process. In order to carry out the dual evaluation on the efficiency and effect, the participants involved in the supervision and evaluation should include management and use department, financial auditing department, and relevant stakeholders like students and teachers[4]. The management of teaching funds should follow the requirements of overall budget management in the university, and a performance objective evaluation mechanism should be introduced[3]. 
After the introduction of the evaluation mechanism, problems in the use of teaching funds can be noticed in time, and the rationality of budgeting can be evaluated, which can help avoid insufficient or surplus in teaching funds, make the teaching funds using more efficient and effective, and provide reference for the next year's teaching funds budgeting.

\section{CONCLUSION}

Improving the management of undergraduate teaching funds is of great significance to improving students' satisfaction and employment rate, and it can guarantee universities to fulfill their social responsibilities. Undergraduate teaching funds management should be controlled during the whole process. Firstly, increase the input of teaching funds, change the current fund shortage existing in universities, give full play to the power of the public, and increase the university cash flow. Secondly, improve the budgeting method. Determine quantitative standards based on the number of students and various disciplines, which can ensure the rationality and accuracy of indicator budgeting. Thirdly, implement the evaluation system. Strengthen the supervision and management during and after the budget implementation. Pay attention to the timely adjustment in the implementation. The teaching departments should be evaluated according to the system, making the related work done and the teaching funds used more efficiently.

\section{ACKNOWLEDGMENT}

First and foremost, this work is supported by "Education and Teaching Reform Project of Tianjin Agricultural University in 2021-- Research on the use and management of teaching funds in local Colleges and Universities. Project Number: 2021-C-26"

I would like to express my gratitude to all those people who helped me during the period of research and the writing of this thesis. Firstly, I acknowledge the help of financial staff of other universities in Tianjin. Thanks for the financial data they provided and guidance and suggestions they gave on related issues in the research and suggestions about thesis writing. Secondly, thanks to my colleagues for their suggestions on the project research and thesis writing. Finally, I would like to express my sincere thanks again to all those who helped me in the successful publication of this thesis.

\section{REFERENCES}

[1]Yin Xuedong, Zhang Xiangjing, Yang Rui, Zheng Jun. An empirical study on the performance investment structure of teaching funds in local colleges and universities -- taking a local college as an example. Accounting Friends. vol. 24, pp. 79-83, December 2018.

[2]Zhang Menghong. Research on problems and Countermeasures of Teaching Funds Management in Colleges and Universities. Journal of Ningde Normal University (Philosophy and Social Science edition). vol. 1, pp. 124-128, March 2019.

[3]Tang Jing, Fu Yan, Wang Still. Study on the effect and evaluation of fund use in Xizang Universities. Journal of Xizang Minzu University (Philosophy and Social Science Edition). vol. 39, pp. 131-135, January 2018.

[4]Lu Ying, LE Xiaodan: Research on the Impact of Investment Structure of Educational Funds on Performance of Local Universities in Jiangsu Province, Research on Educational Finance and Accounting. vol. 24, pp. 16-21, December 2013.

[5]Liu Hong. Research on fine management of teaching Funds -- Taking M University as an example. Finance and Economics. vol. 8, pp. 19-20, August 2021.

[6]Liu Jingyan. Research on the investment management of university teaching Funds after the increase of education investment. Modern Trade Industry. vol. 4, pp. 157-158, April 2015. 